IRA-International Journal of Education \& Multidisciplinary Studies

ISSN 2455-2526; Vol.03, Issue 03 (2016)

Institute of Research Advances

http://research-advances.org/index.php/IJEMS

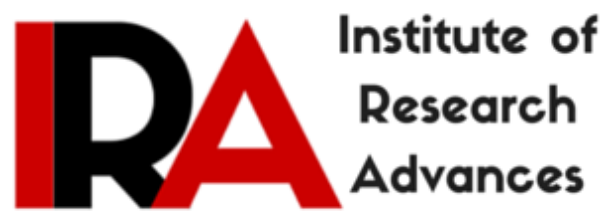

\title{
Prevailing Educational Philosophies among Pre-Service Teachers
}

\author{
${ }^{1}$ Joshua B. Tupas \\ West Visayas State University-Janiuay Campus \\ Cabesa Jose D. Brana Street \\ Janiuay, Iloilo, Philippines. \\ ${ }^{2}$ Guiller P. Pendon \\ West Visayas State University-Janiuay Campus \\ Cabesa Jose D. Brana Street \\ Janiuay, Iloilo, Philippines.
}

\section{DOI: http://dx.doi.org/10.21013/jems.v3.n3.p16}

\section{How to cite this paper:}

B. Tupas, J., \& P. Pendon, G. (2016). Prevailing Educational Philosophies among Pre-Service Teachers. IRA International Journal of Education and Multidisciplinary Studies (ISSN 2455-2526), 3(3).

doi:http://dx.doi.org/10.21013/jems.v3.n3.p16

(C) Institute of Research Advances

\section{(cc) EY-NC}

This works is licensed under a Creative Commons Attribution-Non Commercial 4.0 International License subject to proper citation to the publication source of the work.

Disclaimer: The scholarly papers as reviewed and published by the Institute of Research Advances (IRA) are the views and opinions of their respective authors and are not the views or opinions of the IRA. The IRA disclaims of any harm or loss caused due to the published content to any party. 


\begin{abstract}
The motivation of this study is derived from the presumption or belief that pre-service teachers are somehow guided by certain philosophies as they enhance their pedagogical skills before practicing their profession. This study aimed to find out the prevailing educational philosophies of pre-service teachers when taken as a whole and when classified according to course, sex, and grade point average (GPA). The respondents of the study were the 67 education students of the West Visayas State UnivesityJaniuay Campus who were chosen through stratified sampling. Data were gathered with the aid of a selfmade philosophic inventory checklist which was validated by experts and pilot- tested. It utilized the descriptive design to collect, analyze and classify data on the prevailing educational philosophies of preservice teachers. Results showed that pre-service teachers were likely to accept existentialism and progressivism as educational philosophies when taken as a whole and when classified according to course, sex and GPA. With the use of Mann-Whitney test, inferential statistics showed that there was no significant difference in the prevailing educational philosophies of pre-service teachers when classified according to course, sex and GPA.
\end{abstract}

Keywords: Educational Philosophies, Pre-Service Teachers, Prevailing

Education is the most important and most noble of human endeavors. All other activities have their foundation in education. It enables humans to achieve their fullest personal, spiritual, mental, social, and physical potentials. The ability of being educated is what distinguishes humans from animals. Education transforms an individual and allows her to effect change in her environment (Sadker, 2008).

Education is a continuing voyage of discovery, an everlasting quest to achieve the fullest wisdom and stature that God meant for us. Education, according to Smeyer (1994), is a lifelong learning process that can take place in an infinite variety of circumstances and contexts. According to Curren (2007), education is "the range of activities both formal and informal whereby people are initiated into or realigned with the evolving traditions, structures, and social relations which are taken to constitute their education."

True education means more than the perusal of a certain course of study. It means more than a preparation for the life that now is. It has to do with the whole being and with the whole period of existence possible to man. It is the harmonious development of the physical, the mental, and the spiritual powers. It prepares the student for the joy of service in this world and for the higher joy of wider service in the world to come (Brewer, 2000).

Educational philosophy is philosophy applied to education as a specific area of human endeavor. It involves bringing those critical reflections which characterize philosophy in general to influence and direct the range of experiences and possessions that may be referred to as education. Philosophy of education does not exist in a vacuum, but within a particular social and historical context (Bandura, 2006).

Educational philosophy, according to Carlson (2008) has three dimensions: (1) the personal,(2) the public, and (3) the professional. The personal dimension has to do with having a set of personal beliefs about what is good, right, and worthwhile in education. The public dimension is aimed at guiding and directing the practice of many. The professional dimension provides specific guidelines for the practice of teaching. The importance of a philosophy of education is that it defines the purpose and focus of an educational institution. It becomes a part of its mission statement which in turn defines what subjects are taught, how they are taught and, perhaps more importantly, the values that are taught both implicitly and explicitly along with the subjects being covered.

According to Lucas (2006), the purpose of education, as described by philosophers, is generally considered to be the reproduction of a culture. This can take several forms. In a conservative environment, it can mean the maintenance of the status quo. In a more liberal environment it means the 
teaching of values that are considered to be desirable. In effect, the schools serve to create a culture and mores that are not currently part of the culture but are perceived as desirable. In any case, it means that the values taught are those of the church, government, or other system that controls the schools.

Whether intended or unintended, schools serve to reproduce a culture. Education is a critical part of a child's socialization (Shaffer, 2000). It is where they learn not just the obvious tools for life but the cultural mores, values and social tools for life. The question I choose to address is who is responsible for determining the sort of training students receive in school.

The educational process depends on four fundamental aspects: the education institution, teachers, curriculums, and the students. These four aspects correlate with each other strongly.

In fact, all aspects are being integrated into the educational process in any educational institutions. Each one of those aspects is working side by side to support the other aspect accurately. It is well known that an educational philosophy reflects a social philosophy. A social philosophy is considered as a plan to guide the educational process. A relation between philosophy and education is unclear; however, there is acceptance for this relations existence. Some people believe that education is a result of philosophical doctrines, and educators are, in fact, philosophers. Moreover, education is a process of keeping and transferring social heritage throughout history.

The educational philosophy helps to understand and to modify the educational process. It helps to identify conflicts and contradictions in any theory. It develops the human capacity to raise questions about theory. Also, it clarifies concepts and assumptions that are underlying educational theories. Vividly, it's clear that the importance of studying the educational philosophy at the present time is to understand deeply the educational process. Each fundamental aspect has a basic function in the education process.

This study entitled "Prevailing Educational Philosophies among Pre-service Teachers" was founded on the following principles:

Firstly, the education institution - the school - is a social educational institution which plays a significant role side by side with other aspects. The primary function of the school is raising the children by transferring the cultural heritage from previous generations. Additionally, within the school environment children learn the basic studies such as: knowledge of religion, history, literature, science, and linguistic. Those studies will be made clear by teaching specific curriculums for each level and gradually, starting from primary education to higher education.

Secondly, the teacher is one of the fundamental aspects of the educational process. The transition from the traditional education system to the E-learning system made some changes in the teachers' role. The teacher is a mentor, director, and educational leader in the educational process. A successful teacher is the one who is able to organize the work and classroom life. Also, he creates a desire in each student to do the work. In the concept of emotional intelligence, a person who's able to understand his emotions has the ability to understand and to control others' emotions. Pursuing this further, the teacher affects the learner both emotional and behavioral ways.

Thirdly, curriculum is not less important than other aspects. It's defined as all the educational experiences that are offered by teachers at the school. Besides that, there are several dimensions that must be accrued in any curriculum. Those dimensions are objectives, content, teaching methods, and assessment. Objectives mean all knowledge that is established by the educational institution and achieved by students. The content is the component of the curriculum which organizes all knowledge in a particular manner in order to achieve all objectives. Both previous dimensions will be explained by the teaching method. It means the way that is used to deliver information by the instructor to students. The assessment aims to determine if the student may have reached all educational objectives in all areas or not. All the previous aspects are working together to create a healthy and educational environment for the student, who's considered a fundamental factor to build the future.

Although there are many different branches of education, the present time requires the presence of philosophy in the field of education, considering that the educational philosophy derives its subject from education. It is a must that teachers and even pre-service teachers have to have his beliefs, values and knowledge anchored on certain educational philosophy to be able to define themselves, the school and the community they share their expertise with. Thus, this study was conducted. 
This study was anchored in transformative learning theory wherein learning refers to the changes the way we see ourselves, those around us, and the world. It is not simply learning new knowledge or skills or extending what we already know into a new topic or domain. It actually changes "what we know". Transformative learning is based on three (3) fundamental activities: learning from experience, critical reflection, and personal development. In learning from experience, experiences can be planned or unplanned and can involve individuals in various ways; eg, cognitively, physically, emotionally. If and how individuals learn from that experience is influenced by their own world view, values, and beliefs. Experience may trigger learning for some and not for others. It is suggested that transformative learning occurs when one cannot easily fit a new experience into their existing knowledge, views, or perspectives. Such a situation stimulates reflection. Critical reflection is a cognitive process by which individuals question existing knowledge and importantly, underlying beliefs and assumptions, including those related to power distribution, and strive to make sense of a new experience. Frequently this process elicits emotional responses. It is the re-examining of long-held beliefs and values that leads to transformative learning.

Along this line of thought, the researcher found it necessary to identify the prevailing educational philosophies among pre-service teachers of the West Visayas State University-Janiuay Campus when classified according to sex, course and GPA.

This study aimed at ascertaining the prevailing educational philosophies of pre-service teachers enrolled during SY 2013-2014 at the West Visayas State University-Janiuay Campus.

Specifically, this study sought answers to the following questions:

1) What are the prevailing educational philosophies of pre-service teachers when taken as a whole and grouped as to sex, course and grade point average (GPA)?

2) Is there a significant difference in the prevailing educational philosophies of pre-service teachers when taken as a whole and grouped as to sex, course and grade point average (GPA)?

\section{Methodology}

This study utilized the descriptive design to collect, analyze and classify data on the prevailing educational philosophies of pre-service teachers. These pre-service teachers are the Bachelor of Elementary Education (BEEd) and the Bachelor of Secondary Education (BSEd) of the West Visayas State University - Janiuay Campus.

As the initial step, the researcher identified the respondents during SY 2014-2015. Identification of student-respondents was based on sex, course and grade point average (GPA).

The researcher constructed a rating scale designed to determine the prevailing educational philosophies of pre-service teachers.

The tentative draft of the philosophic inventory checklist was submitted for validation to a panel of jurors who are expert in the field of educational philosophies. It was pilot-tested in order to determine the reliability of each item. After the questionnaire was revised and finalized, permission to conduct the study was secured from the campus administrator and the instrument was distributed to pre-service teachers at the West Visayas State University-Janiuay Campus. The researcher gathered the accomplished instruments as soon as the respondents finished answering them.

The answers of the pre-service teachers in the philosophic inventory checklist were used as the basis in determining their prevailing educational philosophies. The data obtained from this investigation were tallied, computer-processed, analyzed and interpreted. 
Table 1

\section{Respondents}

Profile of the Respondents as to Course, Sex and GPA

\begin{tabular}{llc}
\hline Categories & $f$ & $\%$ \\
\hline Entire group & 67 & 100 \\
Course & 51 & 76 \\
BEED & 16 & 24 \\
BSED & & \\
Sex & 8 & 12 \\
Male & 59 & 88 \\
Female & & \\
Grade Point Average & 18 & 27 \\
High & 49 & 73 \\
Low & & \\
\hline
\end{tabular}

\section{Research Instrument}

The data-gathering instrument that was used in the study was a self-made philosophic inventory checklist which was validated by the panel of experts. The instrument consists of two parts. Part One requires personal data such as name, sex, course and grade point average. Part Two is the instrument proper which contains thirty-six (36) item statements utilized to draw out the respondents' prevailing educational philosophies. Six (6) items are assigned to relate to and focus on each six common philosophies in education, namely, essentialism, behaviorism, progressivism, existentialism, perennialism, and reconstructionism.

There were five responses to be determined: Strongly Disagree, Somehow Disagree, Somehow Agree, Agree, and Strongly Agree.

"Strongly Disagree" means that the respondents do not entirely accept, agree or believe in the given statements.

"Somehow Disagree" means that the respondents are somewhat in doubt, more or less differs in belief, and yet unlikely to accept the concepts or ideas presented in the checklist.

"Somehow Agree" means that the respondents are somewhat in doubt, more or less differs in belief, and yet likely to accept the concepts or ideas presented in the checklist.

"Agree" means that the respondents positively accept or believe the given statements. statements.

"Strongly Agree" means that the respondents totally accept or believe the given concepts or

In determining the results an arbitrary scale was used:

$\begin{array}{ll}\text { Scale of Mean } & \text { Description } \\ 1.0-1.80 & \text { Strongly Disagree } \\ 1.81-2.60 & \text { Somehow Disagree } \\ 2.61-3.40 & \text { Somehow Agree } \\ 3.41-4.20 & \text { Agree } \\ 4.21-5.00 & \text { Strongly Agree }\end{array}$


Table 2

\section{Findings}

Means and Standard Deviations Prevailing Educational Philosophies of Pre-Service Teachers when Taken as a Whole and Classified According to Course, Sex and GPA

\begin{tabular}{llll}
\hline Categories & Mean & $S D$ & Description \\
\hline Entire group & 3.23 & .26 & Somehow Agree \\
Course & & & \\
BEED & 3.24 & .24 & Somehow Agree \\
BSED & 3.19 & .32 & Somehow Agree \\
Sex & & & \\
Male & 3.34 & .33 & Somehow Agree \\
Female & 3.22 & .25 & Somehow Agree \\
Grade Point Average & & & \\
High & 3.25 & .23 & Somehow Agree \\
Low & 3.23 & .27 & Somehow Agree \\
\hline
\end{tabular}

Table 3

Means, Standard Deviations and Rank of Prevailing Educational Philosophies of Pre-Service Teachers when Classified According to Course

\begin{tabular}{lllll}
\hline Categories & Mean & SD & Description & Rank \\
\hline $\begin{array}{l}\text { Course } \\
\text { BEEd }\end{array}$ & & & \\
$\quad$ Essentialism & 2.52 & .64 & Somehow Agree & 6 \\
$\quad$ Behaviorism & 2.93 & .46 & Somehow Agree & 5 \\
$\quad$ Progressivism & 3.64 & .38 & Agree & 1 \\
Existentialism & 3.52 & .38 & Agree & 2 \\
Perennialism & 3.37 & .39 & Somehow Agree & 4 \\
Reconstructionism & 3.47 & .47 & Agree & 3 \\
BSEd & & & & \\
$\quad$ Essentialism & 2.81 & .64 & Somehow Agree & 6 \\
Behaviorism & 2.87 & .48 & Somehow Agree & 5 \\
$\quad$ Progressivism & 3.65 & .49 & Agree & 1 \\
Existentialism & 3.52 & .40 & Agree & 2 \\
$\quad$ Perennialism & 3.24 & .48 & Somehow Agree & 4 \\
Reconstructionism & 3.26 & .48 & Somehow Agree & 3 \\
\hline
\end{tabular}


Table 4

Means, Standard Deviations and Rank of Prevailing Educational Philosophies of Pre-Service Teachers when Classified According to Sex

\begin{tabular}{lllll}
\hline Categories & Mean & SD & Description & Rank \\
\hline Sex & & & & \\
Male & & & & \\
Essentialism & 3.0 & .50 & Somehow Agree & 5 \\
Behaviorism & 2.92 & .44 & Somehow Agree & 6 \\
Progressivism & 3.65 & .42 & Agree & 2 \\
Existentialism & 3.68 & .44 & Agree & 1 \\
Perennialism & 3.33 & .50 & Somehow Agree & 4 \\
Reconstructionism & 3.46 & .59 & Agree & 3 \\
Female & & & & \\
Essentialism & 2.53 & .60 & Somehow Agree & 6 \\
Behaviorism & 2.87 & .49 & Somehow Agree & 5 \\
Progressivism & 3.64 & .41 & Agree & 1 \\
Existentialism & 3.50 & .37 & Agree & 2 \\
Perennialism & 3.34 & .40 & Somehow Agree & 4 \\
Reconstructionism & 3.41 & .48 & Agree & 3 \\
\hline
\end{tabular}

Table 5

Means, Standard Deviations and Rank of Prevailing Educational Philosophies of Pre-Service Teachers when Classified According to Grade Point Average (GPA)

\begin{tabular}{lllll}
\hline Categories & Mean & SD & Description & Rank \\
\hline GPA & & & & \\
High & & & & \\
Essentialism & 2.45 & .62 & Somehow Agree & 6 \\
Behaviorism & 2.85 & .57 & Somehow Agree & 5 \\
Progressivism & 3.71 & .33 & Agree & 1 \\
Existentialism & 3.45 & .46 & Agree & 3 \\
Perennialism & 3.42 & .46 & Agree & 4 \\
Reconstructionism & 3.60 & .41 & Agree & 2 \\
Low & & & & \\
Essentialism & 2.63 & .59 & Somehow Agree & 6 \\
Behaviorism & 2.87 & .45 & Somehow Agree & 5 \\
$\quad$ Progressivism & 3.62 & .44 & Agree & 1 \\
Existentialism & 3.55 & .35 & Agree & 2 \\
$\quad$ Perennialism & 3.31 & .39 & Somehow Agree & 4 \\
Reconstructionism & 3.35 & .49 & Somehow Agree & 3 \\
\hline
\end{tabular}


Table 6

\section{Inferential Data Analysis}

Mann-Whitney Test result for Significance of Difference in the Prevailing Educational Philosophies of Pre-Service Teachers when Classified According to Course, Sex and GPA

\begin{tabular}{lccc}
\hline Categories & Mean Rank & $Z$ & Assymp. Sig.(2-tailed) \\
\hline Course & 35.17 & -.876 & .38 \\
BEED & 30.28 & & \\
BSED & & & .26 \\
Sex & 41.25 & -1.123 & \\
Male & 33.02 & & .729 \\
Female & & & \\
GPA & 35.36 & -.347 & \\
High & 33.50 & & \\
Low & & & \\
\hline
\end{tabular}

$* p>.05$, Not Significant

\section{Discussion}

Findings showed that when taken as a whole, and classified according to course, sex, and grade point average (GPA), the scores of the pre-service teachers of WVSU-Janiuay on prevailing educational philosophies were described as "somehow agree". This means that both BEEd and BSEd students, regardless of sex and GPA, are likely to embrace a certain educational philosophy with inclinations to possess beliefs or concepts, although they do not strongly advocate or single out one among the six common educational philosophies.

When taken as a whole, and classified according to course, sex and GPA, the pre-service teachers' scores on essentialism were described as "somehow agree." This implies their impartial but not total inclination to embrace the beliefs of essentialism as an educational philosophy, in spite of their sex and GPA, whether they are BEEd and BSEd students.

Because essentialism integrates progressive and traditional education in order to focus on the moral, pedagogical challenge of providing a liberal arts curriculum to every child in the nation (Null, 2007), it can be inferred that students of WVSU-Janiuay somehow believed that teaching is a set of "essential" core courses designed to continue traditional academic knowledge. But is it conclusive to state that these pre-service teachers generally perceive teachers as the source of knowledge and education as anything but a reflection and transmission of both culture and tradition?

Essentialists believe in education that stresses the fundamentals. Modern essentialists favor going "back to the basics" of the traditional curriculum (Marino, 2004). In essentialism, teachers think that they should educate every man's child. Essentialists are oriented more in their outlook to their subject matter than their students. It could be thus realized that the pre-service teachers somehow agree that instruction is teacher-oriented and is focused on the intellectual growth of students - not their social, emotional, or physical development.

As to behaviorism, the outcome of the test is the same with that of essentialism. When taken as a whole, and classified according to course, sex and GPA, the pre-service teachers somehow agree with the concepts and principles of behaviorism.

In behaviorism, learners are considered as passive learners. Does this say something about the result of the test?

Behaviorism has had a pronounced impact on educational practice. It is of course common for teachers and parents to reinforce such things as giving correct responses to questions. The programmed 
instruction and teaching machines of some decades ago worked on Skinnerian principles, in that correct responses to questions were acknowledged and praised virtually instantly (Huitt \& Hummel, 1998). Many elements of behaviorism are still to be found in the work of some contemporary educational researchers, who 'operationally define' their concepts (that is, define them in observable terms), and who use so-called 'objective measures' that they believe do not rely on making judgments about the subjective beliefs and commitments of those who are being studied.

In assuming that human behavior is learned, behaviorists also hold that all behaviors can also be unlearned, and replaced by new behaviors; that is, when a behavior becomes unacceptable, it can be replaced by an acceptable one. A key element to this theory of learning is the rewarded response. The desired response must be rewarded in order for learning to take place (Parkay \& Hass, 2000). In education, advocates of behaviorism have effectively adopted this system of rewards and punishments in their classrooms by rewarding desired behaviors and punishing inappropriate ones. Rewards vary, but must be important to the learner in some way.

Behaviorist techniques have long been employed in education to promote behavior that is desirable and discourage that which is not. Among the methods derived from behaviorist theory for practical classroom application are contracts, consequences, reinforcement, extinction, and behavior modification. Using behaviorist theory in the classroom can be rewarding for both students and teachers. Behavioral change occurs for a reason; students work for things that bring them positive feelings, and for approval from people they admire. They change behaviors to satisfy the desires they have learned to value. They generally avoid behaviors they associate with unpleasantness and develop habitual behaviors from those that are repeated often (Parkay \& Hass, 2000). The entire rationale of behavior modification is that most behavior is learned. If behaviors can be learned, then they can also be unlearned or relearned.

It can be implied from all these that the pre-service teachers of WVSU-Janiuay do not entirely agree with the behavioristic belief on behavior modification or learning as a set of learned responses. Somehow, subjective beliefs and individual judgment and commitment get in the way in the learning process. It appears, then, that these students do not possess strong leanings toward behavioristic and essentialistic principles.

Despite these results, however, the scores of pre-service teachers on progressivism show that they consistently agree with progressivism, when taken as a whole, and classified according to course, sex and GPA. Both male and female, whether they are BEEd and BSEd students or they have high or low GPA, accepted progressivism.

The result is understandable, since progressivism is the ideological enemy of essentialism, and while behaviorism does not considered subjective implications in the field of learning but rather controlled responses, essentialism forgets to look into the emotional, social and physical well-being of the learners. Essentialists claim that progressives are premature in trying to teach students to think and solve problems before they have first acquired a body of reliable knowledge to think in terms of. In other words, essentialists feel that you can't think in terms of a vacuum.

Progressivism begins the shift from teacher-centered to student-centered philosophies. Progressivism, as put forth by John Dewey, is very pragmatic and scientific in the way students approach learning (Sadker \& Sadker, 2008). Knowledge is attacked as a puzzle to be solved using previous knowledge and orderly steps for discovery. The teacher serves as a guide for students and encourages them to learn through real-life situations. The curriculum is focused on the needs of the students to develop real world functioning skills. As Dewey believes schools should be "institution[s] engaged in opening a path toward a more democratic, humane, equitable, just, and sustainable tomorrow; and thus an institution engaged not in reproducing and legitimating inequality but in challenging it, not in promoting norms of docility but rather norms of democratic civility" (Carlson, 2007).

These concepts could be a justified and sufficient reason for pre-service teachers' positive acceptance of progressivism. Students are the core beings of instruction as teachers act as guides to attend to their special needs. 
As to existentialism, the outcome of the test is the same with that of progressivism. When taken as a whole, and classified according to course, sex and GPA, the pre-service teachers agree with the concepts and principles of existentialism.

Again, the result is understandable. Let's take a look at the existentialist's basic tenets.

It must be noted that existentialism is the most student-centered of all of the philosophies and perhaps the most polar opposite of essentialism. Uniqueness and individuality are highly valued in the existentialist classroom. Existentialism is a philosophy based on the notion that man's existence is an internal, subjective experience (Karl and Harnalian 1993). It holds that beyond mere existence lies essence, which can be achieved by those who actively seek to discover purposefulness in their existence and to attribute personal meaning to it (Fitzgerald, 2005). They do this by making authentic, independent choices and by assuming responsibility for the consequences of those choices throughout their lives.

Once teachers recognize that reality is experienced subjectively, they must then respect and nurture their students' subjective realities. Teachers can do this by providing students with opportunities to make meaningful choices and decisions in the classroom. In encouraging students to have "the courage to be," teachers are essentially providing them with opportunities to rehearse for life's main event: adulthood (Tillich, 1998). By continually reminding students of their personal freedom and by encouraging them to courageously transcend the temptation to avoid and deny freedom, and thereby escape responsibility for consequences, teachers will help students to develop confidence in their decision-making abilities. According to David (2008), the more confident students become, the more autonomous their decisions will be, and the less they will need to rely on the influence of others in making decisions.

That's why pre-service teachers are likely to prefer progressivism and existentialism to essentialism and behaviorism, considering the fact that both progressivism and existentialism emphasize subjectivity and student-centered instruction.

When taken as an entire group, and grouped according to course, sex and GPA, the scores of the pre-service teachers on perennialism are described as "somehow agree". Data, however, show that students with high GPA are likely to accept perennialism as their philosophy compared to those who have low GPA. It is apparent that little insight or the lack of it have created the disparity or difference and knowledge and intelligence is an influential factor, since those pre-service teachers who are considered smart because they have high GPA are likely to accept perennialism as an educational philosophy.

The reason why pre-service teachers who have high GPA are likely to accept it as an educational philosophy could be traced to its logical "structure". Perennialism focuses on the study of classical ideas as espoused through literature. Their core consists of "books, ideas, and concepts" (Sadker \& Sadker, 2008). Perennialism, as the name suggests, admires enduring or everlasting ideas in spite of the change in world around us. Marlow Ediger suggests, "the intermediate role of the school as particular social institution is to teach and the students how to think (that is, wisdom) of the past" (Marlow, 2003). If a student is not engaged through the rigorous pursuit of enduring scholarly truths, they are considered to be on a vocational track in life. Perennialists think it is important that individuals think deeply, analytically, flexibly, and imaginatively.

Hence, students with high GPA tend to embrace perennialism as an educational philosophy because of its focus on logic and individual capacity to think analytically but the passive characteristic of the learner, since teachers have the sole hand in interpreting realities, might have influenced students' results in the test.

Finally, when taken as an entire group, or grouped according to sex, the scores of pre-service teachers revealed that they accept reconstructionism as an educational philosophy but when grouped according to course, BEEd students tend to accept reconstructionism while BSEd students somehow agree with such philosophy. In addition to this, pre-service teachers with high GPA are inclined to accept reconstructionism while the scores of those with low GPA are described as "somehow agree", meaning that they are somewhat in doubt and yet likely to accept the reconstructionist's concepts or beliefs.

The positive acceptance of reconstructionism as an educational philosophy by the pre-service teachers could be attributed to the fact that many writers view it as only an extension of progressivism, 
which the pre-service teachers also accept as educational philosophy. Like progressivism, reconstruction is based on the "pure" philosophy of pragmatism.

Reconstructionism, as put forth by Harold Rugg, George Counts, and Theodore Brameld, aims for "students to learn to identify problems, methods, needs, and goals and to implement aggressive strategies for effecting change." (Reed \& Davis, 2011) In the student's attempts to instigate social changes, the teacher is their mentor. The teacher's duty is to take the academic and personal goals of the student and find a correlation between that and an issue facing society. Students become involved in the community at large instead of restricted to their academic community.

The learning conditions for students in a reconstructionism environment boast "group learning experiences and cooperation with the community." (Reed \& Davis, 2011) The group learning experiences must be authentic, require immediate social action, and have internal value to the students. Not only do the students benefit from such a curriculum, but the community also receives something tangible in return for their tax money, and students receive valuable life lessons which strive to make them true humanitarians.

As they see it, the teacher's main role is that of a resource person or a research project director who guides the students' learning rather than being a dispenser of knowledge. In this role, the teacher carries on a dialogue with students, helping them identify problems, frame hypotheses, find data, draw appropriate conclusions, and select efficacious courses of action (praxis).

Thus, students of WVSU-Janiuay are likely to favor reconstructionism as an educational philosophy because of its emphasis on student's learning and teachers being guides in the learning process. The disparity of the results of scores between BSEd and BEEd students, however, could not be explained as this requires further study and re-consideration of other factors affecting their choice and preference. The same thing is true with students with high and low GPA.

With the use of Mann-Whitney Test, inferential statistics showed that there was no significant difference that existed in the prevailing educational philosophies of pre-service teachers when taken as a whole, and when classified according to course, sex and GPA.

\section{Conclusions}

In view of the findings, the following conclusions were deduced:

The study revealed that students are likely to accept progressivism, existentialism and reconstructionism as educational philosophies. These philosophies have commonalities, for which reason pre-service teachers preferred them to other given philosophies; namely, essentialism, behaviorism, and perennialism. One common attribute of these philosophies is that they embrace student-centered instruction and the other is that, teachers become guides, mentors and directors in the teaching-learning process.

As we all know, progressivism centers the curriculum around the experiences, interests, and abilities of students. Teachers plan lessons that arouse curiosity and push the students to a higher level of knowledge.

In a progressivist school, students are encouraged to interact with one another and to develop social virtues such as cooperation and tolerance for different points of view. Also, teachers feel no compulsion to focus their students' attentions on one discrete discipline at a time, and students may be responsible for learning lessons that combine several different subjects.

Progressivists emphasize in their curriculum the study of the natural and social sciences. Teachers expose students to many new scientific, technological, and social developments, reflecting the progressivist notion that progress and change are fundamental. Students are also exposed to a more democratic curriculum that recognizes accomplishments of women and minorities as well as white males. In addition, students solve problems in the classroom similar to those they will encounter outside of the schoolhouse; they learn to be flexible problem solvers.

In existentialism, education promotes self-worth, and takes into account individual learners as opposed to a prescribed curriculum that disregards individuality. Independent learning is empowered by the use of technology. Existentialists insist on the subject matter and method for investigation and 
teaching which appeal to feelings, emotional creativity and deeper meaning of life; and totally avoid the training and data based education. For them schools should cultivate insight fidelity, love and creative knowledge.

In reconstructionism, curriculum focuses on student experience and taking social action on real problems, such as violence, hunger, international terrorism, inflation, and inequality. Strategies for dealing with controversial issues (particularly in social studies and literature), inquiry, dialogue, and multiple perspectives are the focus. Community-based learning and bringing the world into the classroom are also strategies.

Reconstructionist educators focus on a curriculum that highlights social reform as the aim of education. Reconstructionists don't believe in a predetermined curriculum. They would use the subject matter from any or all disciplines when needed to solve a problem. They would probably deal more, however, with the subject matter of social experience (the social sciences) in solving problems.

While it is true that these three educational philosophies focus on subjectivity in taking into account the learner's experience in the educative process, the result of the study may well convince us that for authentic, flexible and credible learning to take place, the curriculum must be suited for learner's abilities and interests based on real life situations. Teachers must realize that instruction should no longer be based on prejudiced traditional practice that considers students as passive learners and teachers as sole interpreters of human experience and ultimate source of knowledge who expect desired responses and behavior in a classroom setting.

Hence, it is recommended that teachers may well use a philosophic inventory to consider preservice teachers' orientation so that teachers may know the methods of instruction, approaches and techniques that they may effectively utilize to cater to students' needs. Teachers, along this line, should consider problem-solving classroom techniques, discovery learning, communicative approach, inquiry method, dialectics, etc. to upgrade and enhance instruction.

The curriculum should focus on subjects that more importantly underlines individuality and free will, social reforms and issues, independence, scientific and technological and social developments.

\section{References}

Bandura, A. (2006). Social foundation of thought and action: A social cognitive theory. Englewood Cliffs, NJ: Prentice Hall.

Brewer, E.W., Campbell, A.C., Petty, G.C. (2000). Foundations of Workforce Education. Dubuque, Iowa: Kendall/Hunt Publishing Company.

Carlson, D. (2008). 2007 AESA Presidential Address: Conflict of the Faculties: Democratic Progressivism in the Age of "No Child Left Behind". Educational Studies (American Educational $\begin{array}{llllll}\text { Studies } & \text { Association), } & 43 & \text { (2) } & \text { 94-113. } & \text { Retrieved from }\end{array}$ http://jessicareadyportfolio.files.wordpress.com/2012/03/my-classroom-philosophy.pdf

Curren, R. (2007) (Ed.) Philosophy of Education: An Anthology. Oxford: Blackwell.

David, W. (2008). Existential Being as Transformative Learning, Pastoral Care in Education: An International Journal of Personal, Social and emotional Development, Vol. 26, No. 2, p.111-118. Taylor and Francis, Rutledge, London. Retrieved from http://dc.cod.edu/philosophypub/30

Ediger, M. (2003). Philosophy of Teaching Reading. Reading Improvement, 40 (3), 126-131. Retrieved from http://jessicareadyportfolio.files.wordpress.com/2012/03/my-classroom-philosophy.pdf

Fitzgerald, B. (2005). An Existential View of Adolescent Development. Adolescence, 40, 793-799. Retrieved from http://jessicareadyportfolio.files.wordpress.com/2012/03/my-classroomphilosophy.pdf 
Huitt, W., \& Hummel, J. (1998). The Behavioral System. Retrieved from: http://www.edpsycinteractive.org/topics/behavior/behovr.html

Karl, F. R., and Harnalian, L. (1963). The existential imagination. Greenwich: Fawcett Publications. Retrieved from http://edu301s12.files.wordpress.com/2012/02/existentialism.pdf

Lucas, C. (2006) (Ed.) What is Philosophy of Education? Toronto: Macmillan.

Marino, G. (2004). Basic Writings of Existentialism, p. ix, 3.Modern Library, USA. Retrieved from http://dc.cod.edu/philosophypub/30

Null, J. W. (2007). William C. Bagley and the Founding of Essentialism: An Untold Story in American Educational History. Teachers College Record 109 (4), 1013-1055. Retrieved from http://jessicareadyportfolio.files.wordpress.com/2012/03/my-classroom-philosophy.pdf

Parkay, F.W. \& Hass, G. (2000). Curriculum Planning (7th Ed.). Needham Heights, MA: Allyn \& Bacon.

Reed, Daisy Frye; Davis, Michael D. (2011). Reconstructionism for UrbanStudents. Clearing House, 72 (5), 291-294. Retrieved from http://jessicareadyportfolio.files.wordpress.com/2012/03/myclassroom-philosophy.pdf

Sadker, M. P., Sadker, D. M. (2008). Teachers, Schools, and Society. 8th ed. Boston:McGraw Hill. Retrieved from http://jessicareadyportfolio.files.wordpress.com/2012/03/my-classroomphilosophy.pdf

Shaffer, D. (2000) Social and Personality Development (4th Ed.). Belmont, CA: Wadsworth/Thompson Learning.

Smeyers, P. (1994). Philosophy of education: Western European perspectives. In T. Husen and N. Postlethwaite (Eds), The International Encyclopedia of Education, 2nd edition. Oxford: Pergamon, pp. 4456-61.

Tillich, P. (1998). The courage to be. New Haven: Vision Press. Retrieved from http://edu301s12.files.wordpress.com/2012/02/existentialism.pdf 


\section{Research Instrument}

\section{A. IDENTIFYING INFORMATION}

Name: (optional) Course: ( ) BEEd ( ) BSED

Sex: ( ) Male

( )Female

GPA:

\section{B. PHILOSOPHIC INVENTORY CHECKLIST}

\section{Instructions:}

The following inventory is to help identify your educational philosophy. Respond to the statements on the scale from 5 "Strongly Agree" to 1 "Strongly Disagree" by circling the number that most closely fits your perspective.

\begin{tabular}{|c|c|c|c|c|c|}
\hline & $\begin{array}{c}\text { Strongly } \\
\text { Disagree } \\
1\end{array}$ & $\begin{array}{l}\text { Somehow } \\
\text { Disagree } \\
2\end{array}$ & $\begin{array}{l}\text { Somehow } \\
\text { Agree } \\
3\end{array}$ & $\begin{array}{c}\text { Agree } \\
4\end{array}$ & $\begin{array}{l}\text { Strongly } \\
\text { Agree } \\
5\end{array}$ \\
\hline $\begin{array}{l}\text { 1. The curriculum should emphasize } \\
\text { essential knowledge, not students' } \\
\text { personal interests }\end{array}$ & & & & & \\
\hline $\begin{array}{l}\text { 2. All learning results from rewards } \\
\text { controlled by the external environment. }\end{array}$ & & & & & \\
\hline $\begin{array}{l}\text { 3. Teachers should emphasize } \\
\text { interdisciplinary subject matter that } \\
\text { encourages project-oriented, democratic } \\
\text { classrooms. }\end{array}$ & & & & & \\
\hline $\begin{array}{l}\text { 4. Education should emphasize the search } \\
\text { for personal meaning, not a fixed body of } \\
\text { knowledge. }\end{array}$ & & & & & \\
\hline $\begin{array}{l}\text { 5. The ultimate aim of education is a } \\
\text { constant, absolute, and universal: to } \\
\text { develop the rational person and cultivate } \\
\text { the intellect. }\end{array}$ & & & & & \\
\hline $\begin{array}{l}\text { 6. Schools should actively involve students } \\
\text { in social change to reform society. }\end{array}$ & & & & & \\
\hline $\begin{array}{l}\text { 7. Schools should teach basic skills, not } \\
\text { humanistic ideals. }\end{array}$ & & & & & \\
\hline $\begin{array}{l}\text { 8. Eventually, human behavior will be } \\
\text { explained by scientific laws, proving there } \\
\text { is no free will. }\end{array}$ & & & & & \\
\hline & $\begin{array}{c}\text { Strongly } \\
\text { Disagree } \\
1\end{array}$ & $\begin{array}{l}\text { Somehow } \\
\text { Disagree } \\
\quad 2\end{array}$ & $\begin{array}{l}\text { Somehow } \\
\text { Agree } \\
3\end{array}$ & $\begin{array}{c}\text { Agree } \\
4\end{array}$ & $\begin{array}{l}\text { Strongly } \\
\text { Agree } \\
5\end{array}$ \\
\hline $\begin{array}{l}\text { 9. Teachers should be facilitators and } \\
\text { resources who guide student inquiry, not } \\
\text { managers of behavior. }\end{array}$ & & & & & \\
\hline $\begin{array}{l}\text { 10. The best teachers encourage personal } \\
\text { responses and develop self-awareness in } \\
\text { their students. }\end{array}$ & & & & & \\
\hline $\begin{array}{l}\text { 11. The curriculum should be the same for } \\
\text { everyone: the collective wisdom of } \\
\text { Western culture delivered through lecture } \\
\text { and discussion. }\end{array}$ & & & & & \\
\hline $\begin{array}{l}\text { 12. Schools should lead society toward } \\
\text { radical social change, not traditional }\end{array}$ & & & & & \\
\hline
\end{tabular}




\begin{tabular}{|c|c|c|c|c|c|c|}
\hline & values. & & & & & \\
\hline 13. & $\begin{array}{l}\text { The purpose of schools is to ensure } \\
\text { practical preparation for life and work, } \\
\text { not to encourage personal development. }\end{array}$ & & & & & \\
\hline 14. & $\begin{array}{l}\text { Good teaching establishes an environment } \\
\text { to control student behavior and to measure } \\
\text { learning of prescribed objectives. }\end{array}$ & & & & & \\
\hline 15. & $\begin{array}{l}\text { Curriculum should emerge from students' } \\
\text { needs and interests: therefore, it should } \\
\text { not be prescribed in advance. }\end{array}$ & & & & & \\
\hline 16. & $\begin{array}{l}\text { Helping students develop personal values } \\
\text { is more important than transmitting } \\
\text { traditional values. }\end{array}$ & & & & & \\
\hline & $\begin{array}{l}\text { The best education consists primarily of } \\
\text { exposure to great works in the Humanities }\end{array}$ & & & & & \\
\hline 18. & $\begin{array}{l}\text { It is more important for teachers to } \\
\text { involve students in activities to criticize } \\
\text { and transform society than to teach the } \\
\text { Great Books. }\end{array}$ & & & & & \\
\hline 19. & $\begin{array}{l}\text { Schools should emphasize discipline, hard } \\
\text { work, and respect for authority, not } \\
\text { encourage free choice. }\end{array}$ & & & & & \\
\hline 20. & $\begin{array}{l}\text { Human learning can be controlled: } \\
\text { Anyone can be taught to be a scientist or a } \\
\text { thief; therefore, personal choice is a myth. }\end{array}$ & & & & & \\
\hline 21. & $\begin{array}{l}\text { Education should enhance personal } \\
\text { growth through problem solving in the } \\
\text { present, not emphasize preparation for a } \\
\text { distant future. }\end{array}$ & & & & & \\
\hline 22. & $\begin{array}{l}\text { Human nature is constant-its most } \\
\text { distinctive quality is the ability to reason; } \\
\text { therefore, the intellect should be the focus } \\
\text { of education. }\end{array}$ & & & & & \\
\hline 23. & $\begin{array}{l}\text { Because we are born with an unformed } \\
\text { personality, personal growth should be the } \\
\text { focus of education. }\end{array}$ & & & & & \\
\hline & $\begin{array}{l}\text { Schools perpetuate racism and sexism } \\
\text { camouflaged as traditional values }\end{array}$ & & & & & \\
\hline & & $\begin{array}{c}\text { Strongly } \\
\text { Disagree } \\
1\end{array}$ & $\begin{array}{l}\text { Somehow } \\
\text { Disagree } \\
2\end{array}$ & $\begin{array}{l}\text { Somehow } \\
\text { Agree } \\
3\end{array}$ & $\begin{array}{c}\text { Agree } \\
4\end{array}$ & $\begin{array}{l}\text { Strongly } \\
\text { Agree } \\
5\end{array}$ \\
\hline & $\begin{array}{l}\text { Teachers should efficiently transmit a } \\
\text { common core of knowledge, not } \\
\text { experiment with curriculum. }\end{array}$ & & & & & \\
\hline 26. & $\begin{array}{l}\text { Teaching is primarily management of } \\
\text { student behavior to achieve the teacher's } \\
\text { objectives. }\end{array}$ & & & & & \\
\hline & $\begin{array}{l}\text { Education should involve students in } \\
\text { democratic activities and reflective } \\
\text { thinking. }\end{array}$ & & & & & \\
\hline 28. & $\begin{array}{l}\text { Students should have significant } \\
\text { involvement in choosing what and how } \\
\text { they learn. }\end{array}$ & & & & & \\
\hline 29. & Teachers should promote he permanency & & & & & \\
\hline
\end{tabular}




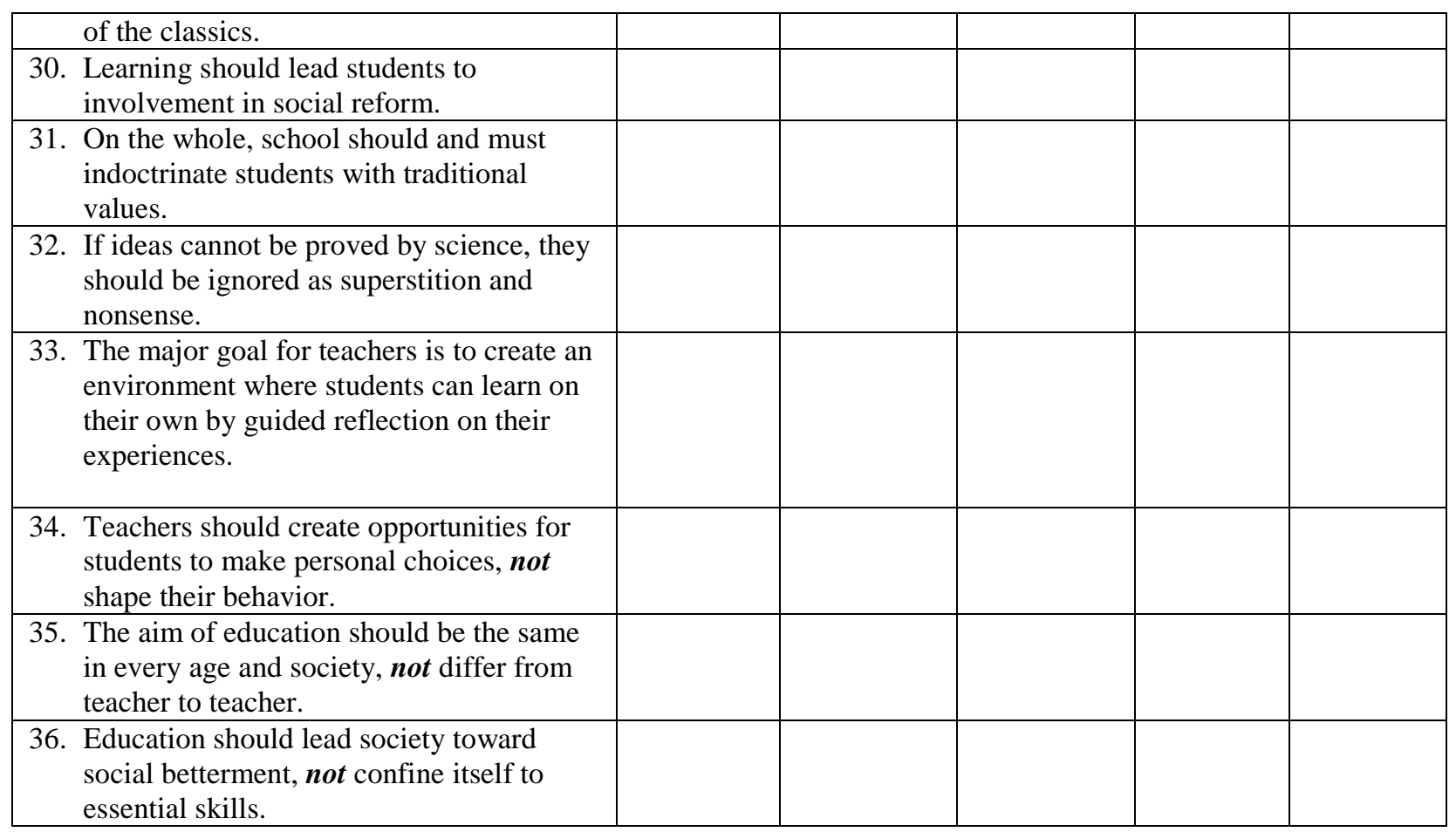

